\title{
A Scientist Looks at the Resurrection
}

\section{Daniel Gordon Ang (1)}

https://doi.org/10.54739/mjqy

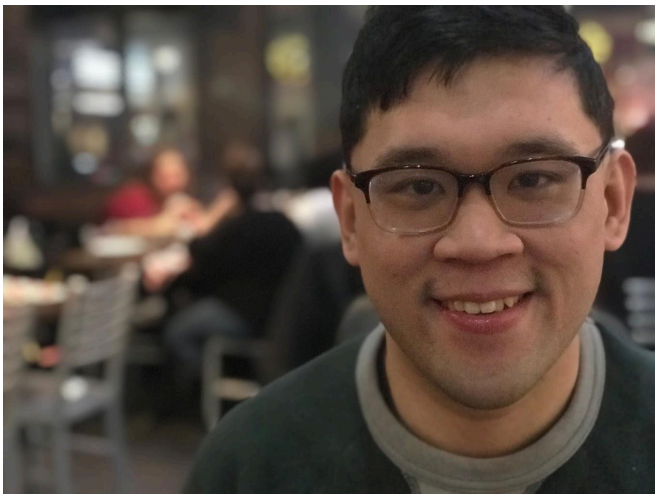

At this point the skeptic may ask: How can I, a scientist, believe in such grandiose, incredible, apparently unscientific claims? How can someone who works with quantum mechanics, molecules, and lasers also believe in the truth of a 2,000-year-old religion and having a personal relationship with a spiritual being?

For me, the bodily resurrection of Jesus is the litmus test for the truthfulness of Christianity. If Jesus genuinely died and rose again, it makes it extremely likely that he was who he claimed to be: the physical incarnation of the Son of God (Matthew 16:16). If it did not happen, then Christianity would be a false religion. A scientist (or any rational person for that matter) would have no reason to believe it to be true.

Clearly, the resurrection of Jesus is unique, even within the context of many other claimed miracles about Jesus. Indeed, it is foundational to the Christian faith. From the days of the early church, it was central to the gospel message they preached: that Christ died for our sins, was buried, rose again, and appeared to many of his disciples ( 1 Corinthians 15:3-6, see also Acts 2:22-32). On the other hand, if Jesus had died and stayed dead like any other human being, then as Paul says, Christians are most to be pitied of all people, for their faith would be based on a lie (1 Corinthians 15:19).

\section{Three Key Facts}

When asked to believe in something, scientists often ask questions about evidence. There certainly is evidence for the Resurrection, which can be summarized around three historical claims: 1) Jesus was crucified and died, 2) his body was buried in a tomb that was found empty a few days later, and 3 ) his disciples experienced encounters with who they believed to be the newly resurrected body. I will show that these three claims, backed by historical evidence and scholarly consensus, together constitute a compelling case for the Resurrection.

The first claim is the least controversial. Almost no historian disputes that Jesus lived in the first century AD, carried out a ministry for a few years and was crucified to death by the Romans. Even a skeptical scholar such as Bart Ehrman argues vigorously for the historical veracity of these basic facts, based on both Christian and nonChristian sources. ${ }^{1}$

1. Bart Ehrman, Did Jesus Exist? The Historical Argument for Jesus of Nazareth. 
The second claim is Jesus' burial and the empty tomb. Skeptical scholars such as Bart Ehrman dispute this, arguing that it is more likely that Jesus' body was left to rot for a few days, then buried in a common pit for criminals. ${ }^{2}$ However, Ehrman's views do not represent a widespread consensus. More comprehensive examinations of Roman crucifixion and Jewish burial practices by specialist scholars show us that the gospel account of Jesus' burial in a tomb by Joseph of Arimathea is historically credible. ${ }^{3}$ Similarly, there are strong arguments to support the claim that the tomb was found empty a few days later. ${ }^{4}$ A commonly cited reason is that the gospel accounts are rendered more credible by their agreement that women were the first witnesses to the empty tomb. More recently, John Granger Cook has argued that based on linguistic, historical, and cultural reasons, it is unlikely Paul mentions a burial and resurrection ( 1 Corinthians 15:3-7) without presupposing an empty tomb. ${ }^{5}$

The third claim is that in the weeks after his death, his disciples claimed to have encountered the risen Jesus. The majority of scholars in the field concur that these visual experiences did occur. ${ }^{6}$ More than mere visual apparitions, the accounts of Jesus' postresurrection appearances are also replete with tactile details (e.g. Matthew 28:9, Luke 24:30,40, John 20:22, 27). Additionally, only a limited number of Jesus' disciples claimed to have witnessed the risen Jesus, as we see in the ancient creed of 1 Corinthians 15:3-7. ${ }^{7}$ Thus, the claimed post-resurrection appearances of Jesus are distinct from incidences of mass psychological hysteria commonly encountered in other religious contexts. ${ }^{8}$

Thus, we have good historical reasons to believe the following claims:

1. Jesus was crucified and died on the cross. (Near-certain)

2. Jesus was buried in a tomb which was found empty a few days after. (Highly probable)

\section{Bart Ehrman, Why Romans Crucified People.}

3. See Craig Evans, The Resurrection of Jesus in the Light of Jewish Burial Practices and John Granger Cook, “ Crucifixion and Burial”, New Testament Studies 57:2 (2011). Besides the fact that the burial by Joseph of Arimathea is consistent with Roman and Jewish laws, we also have archaeological evidence of the remains of a crucified person who was given a proper burial.

4. The aforementioned Habermas article explains that $75 \%$ of scholars discussing the empty tomb accept arguments for its historicity. While this is not unanimous consensus, NT scholar Jonathan Bernier explains in his blogpost Consensus and Quackery that such majority-but-not-unanimous support is also the case for commonly cited statements about the Gospels such as Markan priority. In short, there are few unanimous claims in NT studies, and having 75\% expert agreement on a historical claim should not be an insignificant factor for a non-scholar deciding how likely it is.

5. John Granger Cook, "Resurrection in Paganism and the Question of an Empty Tomb in 1 Corinthians 15”, New Testament Studies 63:1 (2017).

6. Gary Habermas, “ Resurrection Research from 1975 to the Present: What are Critical Scholars Saying?”, Journal for the Study of the Historical Jesus, 3.2 (2005), pp. 135-153.

7. Tim and Lydia McGrew point out that after the detailed, tactile appearances described in the gospel stopped abruptly; even the appearance to Paul ( $\underline{\text { Acts }}$ 9:3-7) is of a distinctively different, more glorified quality. See McGrew and McGrew, "The argument from miracles: a cumulative case for the resurrection of Jesus of Nazareth" in Craig \& Moreland (eds.), The Blackwell Companion to Natural Theology.

8. Jake O'Connell gives a thorough and novel argument that the collective appearances of the post-resurrected Jesus are substantially different even compared to more recent reported collective religious visions (e.g. Marian apparitions). See O'Connell, " Jesus' resurrection and collective hallucinations", Tyndale Bulletin 60(1):69-105.
3. Over the few weeks after and in multiple instances, several of Jesus' disciples encountered a person they believed to be the risen Jesus. (Near-certain)

What theory can best explain these three facts? Skeptics have proposed a wide array of non-supernatural explanations. ${ }^{9}$ For example, it could be that some disciples of Jesus stole the body ( Matth ew 28:15), the disciples were experiencing mass group hallucinations, they went to the wrong tomb, or even that Jesus survived his crucifixion somehow. A combination of these alternative theories could be coincidentally true at the same time, resulting in the improbable but not impossible illusion that Jesus was resurrected.

However, once one removes the requirement that some nonsupernatural explanation must be true, it seems clear to me that the theory that Jesus rose from the dead is a much more plausible explanation than any of the other ones. ${ }^{10}$ One cannot dismiss this as a " god of the gaps" explanation. The resurrection hypothesis is limited and straightforward: it simply says that somehow, Jesus experienced a resurrection which restored his body completely, such that afterwards, he was able to be seen, heard, and touched by the disciples on several occasions.

Now, some might have independent reasons for assuming that supernatural explanations are a priori improbable. More specifically, a scientist might feel specially compelled to disbelieve the claim of supernatural occurrences. After all, one of the narratives of scientific progress is that things which we thought to be supernatural before turned out to have mundane scientific explanations. Isn't it more judicious for careful scientists to be agnostic and assume that a better, non-supernatural explanation can someday be found?

With these objections in mind, there is potential wriggle room for some rational skepticism, but we shouldn't overstate this wriggle room. Firstly, science cannot disprove the Resurrection, as we no longer have empirical access to the body of Jesus or any other relevant physical evidence. Secondly, the Resurrection is a one-time phenomenon that does not conform to the regularity and repeatable pattern of most events studied by science. Science is agnostic about such events. Thus, if one wants to remain skeptical, one cannot say that science compels them to do so.

\section{The Personal Evidence}

As we have just discussed, there is strong evidence that Jesus' resurrection happened. However, this evidence is not definitive. Alternate explanations are available. As a scientist, I understand why someone might see this and still walk away in unbelief. In my opinion, historical evidence gives us a rational foundation to trust in Jesus, but it is not enough. This is unsurprising, as the gospels themselves were not originally written for the purpose of proving skeptics wrong.

9. Andrew Loke exhaustively categorizes the possible hypotheses in Loke, "The resurrection of the Son of God: a reduction of the naturalistic alternatives", Journal of Theological Studies 60 (2009): 570-584.

10. Thorough comparisons of competing explanatory power of the different proposed theories can be found in William Lane Craig's Reasonable Faith and Michael Licona's The Resurrection of Jesus: A New Historiographical Approach. If I were forced to take a naturalistic position, to me the most plausible theory would obviously be mass hallucination, which is also dealt with in detail by the O'Connell paper cited above. 
Rather, they were "...written so that you may believe that Jesus is the Christ, the Son of God, and that by believing you may have life in his name " ( John 20:31, ESV). If Jesus is real, then He calls us to eternal life, not rational insight.

My own faith in Jesus works like this. It is informed by the evidence, but it is much more than that. After examining the evidence, at some point I chose to suspend any remaining doubts and see what would happen if I acted as if it was all real. A cynical skeptic might comment that I am merely imagining things. But to me, Jesus' call is unrelenting, and the historical evidence gives me further rational reasons not to ignore it. And Jesus certainly does not want me to know him like I know cold, dispassionate facts about molecules or electrons. Instead, he wants me to know him as a living, personal, loving God. He challenges me to stop treating him like a philosophical proposition and surrender all to him, the God-man who showed through his resurrection that he has achieved victory over death. He gives us reason to hope that one day, all of us, too, will be resurrected as he was, "in a moment, in the twinkling of an eye, at the last trumpet” ( 1 Corinthians 15:52, ESV).

So I choose to believe. In doing so, I join in the confession of millions of Christians throughout time and space who also chose to follow Christ and let him change their hearts, minds, and way of life. The more I choose to surrender my life to Jesus, the more I grow in my relationship and trust in him. Far from undermining my scientific work, my faith gives it a purpose, meaning, and ultimate foundation. It is a foundation that I hope every person reading these words will share at some point.

\section{References}

https://discourse.peacefulscience.org/t/_/4359

https://discourse.peacefulscience.org/t/_/2321

https://www.nature.com/articles/s41586-018-0599-8

https://www.danielang.net/2018/10/17/introducing-the-acme-edmexperiment-2

http://sitn.hms.harvard.edu/flash/2018/frustrating-search-new-physics

https://www.biblegateway.com/

passage/?search=Matthew+16\%3A16\&version=ESV

https://www.biblegateway.com/

passage/?search=1+Corinthians $+15 \% 3 \mathrm{~A} 3-6$ \&version=ESV

https://www.biblegateway.com/

passage/?search=Acts $+2 \% 3 \mathrm{~A} 22-32 \&$ version=ESV

https://www.biblegateway.com/

passage/?search=1+Corinthians+15\%3A19\&version=ESV

https://peacefulscience.org/articles/robert-canfield/

https://en.wikipedia.org/wiki/Bart_D._Ehrman

https://peacefulscience.org/books/jesus-exist/

http://lagrange.academia.edu/JohnGrangerCook

https://www.biblegateway.com/

passage/?search $=1+$ Corinthians $+15 \% 3 \mathrm{~A} 3-7 \&$ version=ESV

https://www.biblegateway.com/

passage/?search=Matthew $+28 \% 3 \mathrm{~A} 9 \% 2 \mathrm{C}+$ Luke $+24 \% 3 \mathrm{~A} 30 \% 2 \mathrm{C}+40 \% 2 \mathrm{C}+\mathrm{John}$

https://www.biblegateway.com/

passage/?search=Matthew $+28 \% 3 \mathrm{~A} 15 \&$ version $=E S V$

https://en.wikipedia.org/wiki/God_of_the_gaps

https://www.merriam-webster.com/dictionary/a\%20priori

http://www.veritas.org/evidence-easter-scientists-list https://www.biblegateway.com/ passage/?search=John+20\%3A31\&version=ESV

https://www.biblegateway.com/ passage/?search=1+Corinthians+15\%3A52\%2C+ESV\&version=ESV

https://ehrmanblog.org/why-romans-crucified-people

https://www.hbu.edu/news-and-events/2016/05/04/craig-evansresurrection-jesus-light-jewish-burial-p-ractices

https://www.cambridge.org/core/journals/new-testament-studies/ article/crucifixion-and-burial/ ABDE509ED99779E09AD59AC274E378A3

http://www.garyhabermas.com/articles/

J_Study_Historical_Jesus_3-2_2005/

J_Study_Historical_Jesus_3-2_2005.htm

https://criticalrealismandthenewtestament.blogspot.com/2014/09/ consensus-and-quackery.html

https://www.cambridge.org/core/journals/new-testament-studies/ article/resurrection-in-paganism-and-the-question-of-an-emptytomb-in-1-corinthians-15/

EF4DE640BE9104A454C7847ECF899313

https://www.biblegateway.com/ passage/?search $=$ Acts $+9 \% 3 A 3-7 \&$ version $=E S V$

https://peacefulscience.org/books/blackwell-companion-naturaltheology/

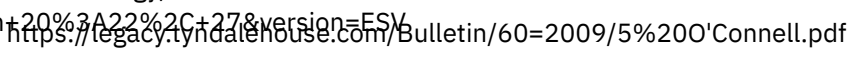

http://www.academia.edu/700274/

Loke_Andrew._The_resurrection_of_the_Son_of_God_a_reduction_of_the_naturalis

https://peacefulscience.org/books/reasonable-faith/

https://peacefulscience.org/books/resurrection-jesus/ 